\title{
Perancangan Program Kampanye Rescue and Adopt Melalui Webtoon Four Little Feet Untuk Membangun Sikap Kepedulian Pada Hewan
}

\author{
Hannah Prisca \\ Sekolah Tinggi Ilmu Komunikasi LSPR, Jakarta, Indonesia
}

\begin{abstract}
ABSTRAK
Perancangan Kampanye Rescue and Adopt Melalui Webtoon "Four Little Feet" untuk Let's Adopt Indonesia merupakan bentuk upaya meningkatkan awareness target audience bahwa setiap anjing dan kucing memiliki hak yang sama untuk mendapatkan kesempatan hidup yang layak. Juga meningkatkan awareness mengenai pentingnya partisipasi masyarakat dalam kegiatan rescue dan adopsi. Hal ini dikarenakan komunitas penyelamat hewan sudah memberikan kontribusi dalam menolong hewanhewan yang terluka, dan terlantar namun jumlahnya masih belum cukup jika dilihat hewan-hewan yang terlantar masih banyak hidup di jalan. Yang menjadi tantangan bagi komunitas ini adalah human resources serta inisiatif masyarakat dalam kegiatan rescue dan adopsi sehingga diharapkan dengan meningkatnya inisiatif, akan mendorong lebih banyaknya hewan tertolong dan pulih, hingga teradopsi.Perancangan materi desain kampanye ini memiliki target audience berusia 16-31 tahun yang mulai dan sudah menginjak dewasa dan lebih bertanggungjawab. Materi kampanye yaitu Webtoon, eposter, dan Line Sticker. Dalam perancangan karya visual kampanye sosial ini, digunakan Sistem Perancangan Kampanye oleh Yongki Safanayong, dimana langkah-langkah pembuatannya meliputi latar belakang fakta, identifikasi masalah, analisis situasi, analisis tantangan dan peluang, strategi kampanye, komponen kampanye/pemilihan media, visualisasi, dan produksi.
\end{abstract}

Kata kunci: Kampanye sosial, desain komunikasi visual, Webtoon, Line Sticker, online media, media sosial, adopsi anjing, adopsi kucing, rescue, pencinta hewan

\begin{abstract}
Rescue and Adopt Campaign Design Through "Four Little Feet" Webtoon for Let's Adopt Indonesia is a way of raising awareness of the target audience that every dog and cat have the same right to get a decent living opportunity. It also raises awareness about the importance of community participation in rescue and adoption activities. The reason is that animal rescue communities have contributed to helping wounded, abandoned animals but the numbers are still insufficient there are still many abandoned animals living on the streets. The challenge for this community is human resources as well as community initiatives in rescue and adoption activities so hopefully with increased initiative, more animals have the oppotunity to be rescued and recovered, until adopted. The design of this campaign design material has a target audience aged 16-31 years who started and have grown up and be more responsible. Campaign materials are Webtoon, e-poster, and Line Sticker. In designing the visual work of this social campaign. The social campaign design materials were adopted from the System Design Campaign by Yongki Safanayong, which measures manufacturing background, including facts, problem identification, analysis of the situation, analysis of challenges and opportunities, campaign strategy, components of the campaign / media selection, visualization, and production.
\end{abstract}

Keywords: Social campaign, visual communication design, Webtoon, Line Sticker, online media, social media, dog adoption, adoption cat, rescue, animal love

CONTACT Hannah Prisca. Sekolah Tinggi Ilmu Komunikasi LSPR Jakarta, Indonesia. Sudirman Park Campus, Jl. Jend. Sudirman No.Kav. 32, RT.12/RW.11, Karet Tengsin, Kota Jakarta Pusat, Daerah Khusus Ibukota Jakarta 10250. Email : hannahpriscahp@gmail.com 


\section{PENDAHULUAN}

Pertumbuhan kelas menengah di Indonesia setiap tahunnya semakin pesat, berdasarkan data Bank Dunia angka nol persen pada tahun 1999 menjadi 6,5 persen pada tahun 2011 yaitu lebih dari 130 juta orang. Pada tahun 2030 jumlah ini diperkirakan akan melesat menjadi 141 juta orang (Alexander, 2016, Februari 4). Seiring naiknya perekonomian kelas menengah, jumlah hewan peliharaan juga semakin bertambah. Dari data yang dimiliki Temali, sebuah komunitas pencinta hewan peliharaan di Indonesia, Indonesia merupakan salah satu negara dengan jumlah hewan peliharaan yang cukup tinggi dengan pangsa pasar mencapai $15,6 \%$ di Asia Tenggara (Julianto, 2016, April 10).

Sayangnya, populasi hewan peliharaan yang kian meningkat ini akhirnya kurang terkontrol. Bahkan menurut Yuli Absari, Kepala Seksi Peternakan Suku Dinas Peternakan dan Perikanan Jakarta Selatan, anjing dan kucing termasuk dalam hewan-hewan yang harus diawasi populasinya (Rio, 2013, Mei 13). Populasi kucing terlantar di Jakarta diperkirakan mencapai 34.000 ekor, kebanyakan dari hewan-hewan ini ditelantarkan oleh pemiliknya dan perkembangbiakannya tidak terawasi (Utomo, 2012, April 15).

People for the Ethical Treatment of Animals (PETA), salah satu organisasi pembela hak hewan terbesar didunia dengan lebih dari 5 juta anggota, menginfokan melalui website resminya, bahwa lebih dari 6 juta anjing dan kucing di Amerika ditangkap dan tinggal di shelter atau tempat penampungan, setiap tahunnya ("Companion Animal Overpopulation", n.d.). Dari keseluruhan jumlah hewan tersebut, 2 sampai 3 juta anjing dan kucing yang kebanyakan sehat dan dapat diadopsi, harus di suntik mati setiap tahun demi menekan jumlah populasi. Hewanhewan ini merupakan hewan yang hilang, ditelantarkan, atau dibuang. Tiga alasan utama penelantaran hewan peliharaan, diantaranya banyak orang yang tidak men-steril anjing atau kucingnya, menyebabkan reproduksi yang tidak diharapkan sehingga jumlah anjing dan kucing yang dimiliki meningkat pesat. Alasan kedua adalah masyarakat masih membeli hewan dari pet shop atau breeder daripada mengadopsi hewan yang tidak memiliki rumah, hal ini juga berefek pada terus berkembangnya jaringan bengembangbiak ilegal puppy mill. Dengan membeli, orang-orang mendapatkan hewan peliharaan tanpa mempertimbangkan komitmen merawat hewan tersebut selama masa hidupnya. Akibatnya, banyak orang yang membuang dan menelantarkan hewan peliharaannya ketika mereka menganggapnya sudah tidak lucu atau merepotkan ("Companion Animal Overpopulation", n.d.).

Populasi hewan peliharaan yang kurang terkontrol disebabkan oleh berbagai alasan, yang paling umum adalah penelantaran karena perkembangbiakan yang tidak diharapkan; maraknya masyarakat yang masih membeli hewan di petshop sehingga industri pengembangbiak ilegal terus berkembang; dan penelantaran akibat kurangnya pertimbangan komitmen merawat hewan hingga akhirnya dibuang ketika dianggap merepotkan.

Tidak hanya di negara maju, isu ini juga berdampak buruk di negara berkembang seperti Indonesia. Contoh paling konkrit adalah wabah rabies yang terjadi di Pulau Bali pada tahun 2008, Kepala Dinas Kesehatan Provinsi Bali Nyoman Sutedja memastikan 35 orang terjangkit rabies positif meninggal dari 74 kasus hingga Juli 2010 ("74 Kasus Rabies di Bali", 2010, Agustus 2). 
Langkah pemusnahan anjing liar sebagai bagian pencegahan rabies menjadi pilihan pemerintah daerah Bali pada tahun 2009. Pembantaian massal dengan suntik mati ini tidak hanya memakan biaya yang besar namun juga menuai kecaman dari berbagai organisasi pembela hak hewan di Indonesia bahkan di dunia karena dianggap tindakan prefentif dapat dilakukan (Setiawan, 2014, Juli 24).

Dalam isu over population ini kesejahteraan hewan telah seringkali menjadi korban dan dilupakan. Anjing dan kucing yang terlantar dan hidup liar di perkotaan dianggap mengganggu oleh beberapa orang, hingga terjadi kasus-kasus penganiayaan yang meresahkan masyarakat. Diantaranya kasus penganiayaan yaitu penembakan kucing yang terjadi di Sleman seperti dikutip Merdeka.com pada Rabu, 5 Maret 2014. Kasus penganiayaan hewan domestik ini tidak sedikit terjadi, hingga membuat para relawan-relawan pencinta hewan beramai-ramai membuat petisi melalui Website Change.org untuk menghentikan pembunuhan dan penganiayaan terhadap hewan peliharaan. Petisi-petisi ini sudah ditanda tangani oleh puluhan ribu orang sebagai bukti kepedulian terhadap keadaan hewan-hewan domestik ini.

Gambar 1. Sejumlah petisi yang dibuat oleh pecinta hewan untuk membela hak hewan-hewan domestik

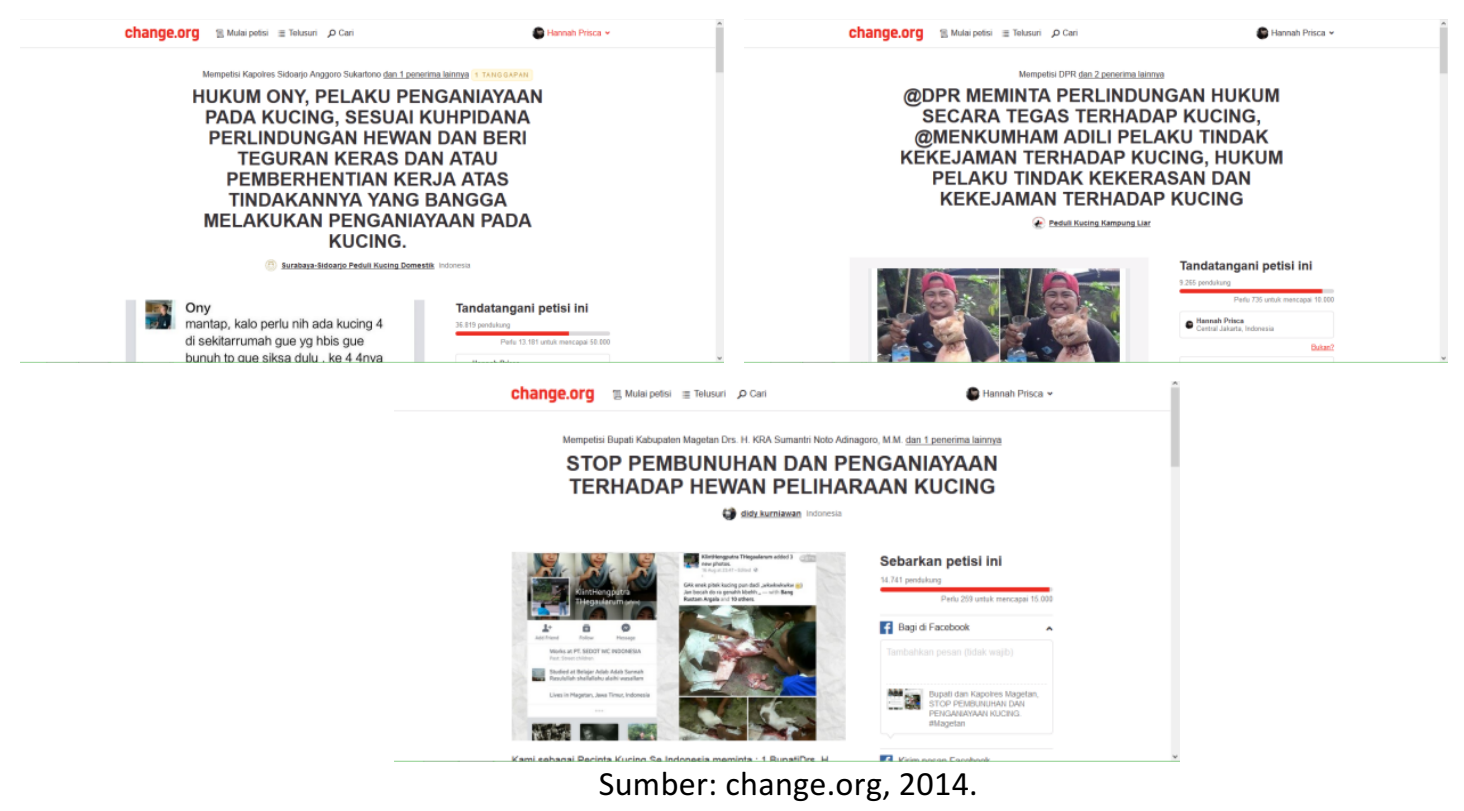

Selain petisi online, berbagai komunitas juga lahir dari kepedulian sekelompok orang terhadap kesejahteraan hewan terutama hewan domestik atau peliharaan. Let's Adopt! adalah salah satu organisasi non-profit yang terbentuk dari motivasi untuk mencapai satu tujuan yaitu menolong hewan yang membutuhkan dimanapun mereka berada. Organisasi internasional ini terbentuk pada Desember 2011 di Massachusetts, Amerika dan berawal dari group Facebook. Organisasi ini berlanjut ke kegiatan-kegiatan penyelamatan hewan aktif berjaringan seperti diungkapkan dalam Website Blog Let's Adopt! Global (“About Us”, n.d.),

Our strength comes from our connections to individuals - rescuers, supporters, advocated, and any person willing to step forward and away from the crowd and make a difference... one animal at a time. 
Let's Adopt! Global kini telah berkembang secara luas menyelamatkan hewan-hewan di berbagai negara diantaranya Amerika, Jerman, Bulgaria, Kanada, dan Indonesia. Let's Adopt! Indonesia merupakan komunitas yang juga terbentuk pada tahun 2011 dan bergerak dibawah organisasi Let's Adopt! Global. Carolina Fajar sebagai founder dari Let's Adopt! Indonesia mengungkapkan komunitas ini mempunyai tujuan yaitu ingin memberikan second chances atau kesempatan kedua untuk hewan yang dulunya terlantar, sakit atau sengaja dibuang untuk memiliki kehidupan yang jauh lebih baik kedepannya (C. Fajar, komunikasi pribadi, Maret 19, 2017). Oleh karena itu kegiatan yang dilakukan meliputi rescue, pengobatan dan pemulihan, mencari foster atau orang tua asuh sementara, kemudian mencari adopter. Selain itu untuk menutup biaya pengobatan donasi selalu dibuka, terkadang juga dilakukan kegiatan fund raise seperti menjual barang.

Let's Adopt! Indonesia menggunakan kerja tim dan jaringan sosial untuk menjalankan misi utamanya menyelamatkan, merehabilitasi dan menemukan rumah permanen untuk hewan dianggap "unrehomable" oleh kelompok-kelompok penyelamat lainnya. Menurut Suri Mulani salah satu koordinator Let's Adopt! Indonesia, Let's Adopt! Indonesia sangat mementingkan kualitas hidup yang ingin diberikan kepada hewan, tidak peduli ras anjing atau kucing tersebut, warna bulu, panjang atau pendek bulu, besar atau kecil, semuanya memiliki hak hidup yang sama (S. Mulani, komunikasi pribadi, Maret 19, 2017). Hal ini juga yang menjadi alasan Let's Adopt! Indonesia sangat terfokus kepada setiap individu hewan.

Lebih dari 200 ekor anjing dan kucing yang diselamatkan oleh komunitas ini, beberapa diantaranya telah berhasil menemukan rumah permanennya di berbagai daerah di Indonesia seperti Semarang, Surabaya bahkan di negara-negara bagian Amerika, Kanada, dan Jerman. Namun masih ada belasan yang belum teradopsi, sedangkan seperti yang telah dipaparkan diatas, jumlah kucing dan anjing yang hidup liar di Jakarta masih mencapai puluhan ribu. Perjuangan yang tidak mudah, namun Let's Adopt! Indonesia terus melanjutkan upayanya menyelamatkan satu persatu hewan yang terbuang ataupun tersiksa. Untuk menyelamatkan lebih banyak lagi hewan seperti Patrick dan Pamela, diharapkan adanya kesadaran dan pengertian masyarakat mengenai kegiatan rescue, dan adopsi.

Gambar 2. Top 25 Negara berdasarkan Jumlah Pengguna Internet 2013-2018

\begin{tabular}{|c|c|c|c|c|c|c|}
\hline & 2013 & 2014 & 2015 & 2016 & 2017 & 2018 \\
\hline 1. China* & 620.7 & 643.6 & 669.8 & 700.1 & 736.2 & $m .0$ \\
\hline 2. US": & 246.0 & 252.9 & 259.3 & 264.9 & 269.7 & 274.1 \\
\hline 3. Indis & 167.2 & 215.6 & 252.3 & 283.8 & 313.8 & 346.3 \\
\hline 4. Brazil & 99.2 & 107.7 & 113.7 & 119.8 & 123.3 & 125.9 \\
\hline 5. Japan & 100.0 & 102.1 & 103.6 & 104.5 & 105.0 & 105.4 \\
\hline 6. Indonesia & 72.8 & 83.7 & 93.4 & 102.8 & 112.6 & 123.0 \\
\hline 7. Russia & 77.5 & 82.9 & 87.3 & 91.4 & 94.3 & 96.6 \\
\hline 8. Germany & 59.5 & 61.6 & 62.2 & 62.5 & 62.7 & 62.7 \\
\hline 9. Mexico & 53.1 & 59.4 & 65.1 & 70.7 & 75.7 & 80.4 \\
\hline 10. Nigeria & 51.8 & 57.7 & 63.2 & 69.1 & 76.2 & 84.3 \\
\hline 11. UK* & 48.8 & S0.1 & 51.3 & 52.4 & $\$ 3.4$ & 54.3 \\
\hline 12. France & 48.8 & 49.7 & 50.5 & 51.2 & 51.9 & 52.5 \\
\hline 13. Phllippines & 42.3 & 48.0 & 53.7 & 59.1 & 64.5 & 69.3 \\
\hline
\end{tabular}

\begin{tabular}{|c|c|c|c|c|c|c|}
\hline 14. Turkey & 36.6 & 41.0 & 447 & 47.7 & 50.7 & 53.5 \\
\hline 15. Vietnam & 36.6 & 40.5 & 444 & 48.2 & 52.1 & 55.8 \\
\hline 16. South Kores & 40.1 & 40.4 & 40.6 & 40.7 & 40.9 & 41.0 \\
\hline 17. Egypt & 34.1 & 36.0 & 38.3 & 40.9 & 43.9 & 47.4 \\
\hline 18. Italy & 34.5 & 35.8 & 36.2 & 37.2 & 37.5 & 37.7 \\
\hline 19. Spain & 30.5 & 31.6 & 32.3 & 33.0 & 33.5 & 33.9 \\
\hline 20. Canada & 27.7 & 28.3 & 28.8 & 29.4 & 29.9 & 30.4 \\
\hline 21. Argentina & 25.0 & 27.1 & 29.0 & 29.8 & 30.5 & 31.1 \\
\hline 22. Colombia & 24.2 & 26.5 & 28.6 & 29.4 & 30.5 & 31.3 \\
\hline 23. Thailand & 22.7 & 24.3 & 26.0 & 27.6 & 29.1 & 30.6 \\
\hline 24. Poland & 22.6 & 22.9 & 23.3 & 23.7 & 24.0 & 24.3 \\
\hline 25. South Africa & 20.1 & 22.7 & 25.0 & 27.2 & 29.2 & 30.9 \\
\hline Worldwide.t.. & 2.692 .9 & 2.892 .7 & 3.072 .6 & 3.246 .3 & $3,419.9$ & $3,600.2$ \\
\hline \multicolumn{7}{|c|}{$\begin{array}{l}\text { Note: individuals of ary age who use the internet from any location via any } \\
\text { device at least once per month" "excludes Hong Kong. "Forecast from Aug } \\
2014 ; \text {; ". includes countries not listed } \\
\text { Source: eMarketer, Nov } 2014\end{array}$} \\
\hline & & & & & & \\
\hline
\end{tabular}

Sumber: kominfo.go.id, 2014.

Pada Januari 2016 dari total populasi di Indonesia 259,1 juta, 88,1 juta merupakan pengguna internet aktif dengan penetrasi $34 \%$, dan 79 juta merupakan pengguna aktif social media 
(Kemp, 2016). Berkembangnya jumlah pengguna media sosial dipengaruhi oleh kemudahan yang ditawarkan dalam pertukaran informasi.

Pengguna media sosial dapat dengan mudah berpartisipasi dalam sebuah percakapan, berbagi informasi, membuat konten, serta berjejaring. Feedback dan kontribusi juga dapat diberikan dalam waktu yang singkat, sehingga memudahkan pengguna mengetahui respon audiens dari konten yang ia buat. Pada pembuatan kampanye ini akan memanfaatkan content share yang dimiliki social media dapat memperluas jangkauan audiensnya.

Webtoon adalah komik online digital yang berasal dan popular di Korea Selatan. Asal mulanya di negara aslinya, Korea pada tahun 1960an, Webtoon merupakan komik tradisional yang dapat dibaca dari media majalah atau buku biasa yang disebut manhwa. Namun seiring berjalannya waktu, buku komik kalah saing dengan konten media modern seperti video, kemudian muncullah inovasi dari buku komik ini ke dalam bentuk yang lebih modern. Menurut Park Soo-In, webtoonist dan doktor dalam studi kartun di Saika University, Kyoto, webtoon memiliki beberapa perbedaan penting dibandingnya platform originalnya yaitu buku komik (Ha Sun Jin, 2012). Webtoon diterbitkan secara digital (dipersonal homepage ataupun komersial website) sehingga tidak memiliki batasan yang dihadapi oleh buku komik yang berbasis cetak. Webtoon dapat memiliki tampilan full color karena tidak harus menekan biaya cetak, selain itu webtoon bisa dilengkapi dengan musik ataupun efek multimedia lainnya.

Kepopuleran budaya K-pop juga membuat tren Korea Selatan lainnya seperti webtoon menjadi terkenal di dunia internasional termasuk di Indonesia. Situs Antaranews.com (2015: 7 Agustus 2015) menyebutkan bahwa salah satu aplikasi atau website komersial untuk membaca webtoon di Indonesia, Line Webtoon, telah diunduh sebanyak 1,5 juta kali dan dibaca oleh 3 juta orang per bulan, serta merupakan aplikasi yang paling banyak diunduh pada Juli 2015. Tahun 2018 ini Line Webtoon sudah didownload sebanyak 10 juta kali. Menurut dgupost.com, webtoon dinilai popular karena beberapa alasan, diantaranya mudahnya komunikasi dan akses. Dalam situs ataupun aplikasi webtoon karena basisnya internet, pembaca dapat berkomunikasi secara langsung dengan pengarang Webtoon, selain itu pembaca dapat menekan tombol share untuk membagi pengalamannya membaca webtoon. Perkembangan new media devices seperti smartphone dan tablet $p c$ juga semakin memudahkan akses membaca Webtoon. Webtoon merupakan media yang menyediakan hiburan melalui cerita dalam bentuk visual yang membawa pembacanya kedalam dunia cerita sejenak. Line Webtoon memiliki karakteristik yang dimiliki media sosial yaitu partisipasi, keterbukaan, percakapan, komunitas, dan saling terhubung.

Manfaat dari program ini adalah merancang kampanye online rescue and adopt melalui Webtoon, Social Media, dan Social Messenger Sticker untuk meningkatkan awareness target audience bahwa setiap anjing dan kucing memiliki hak yang sama untuk mendapatkan kesempatan hidup yang layak guna meningkatkan awareness mengenai pentingnya partisipasi masyarakat dalam kegiatan rescue dan adopsi.

Kampanye merupakan sebuah pemecahan masalah kritis dengan melakukan suatu kegiatan komunikasi atau rangkaian pesan terencana yang spesifik (Safanayong, 2006). Masalah yang ingin dipecahkan dapat berupa masalah komersial ataupun masalah non komersial, seperti masalah sosial, budaya, politik, lingkungan hidup. 
Dalam bukunya, Ruslan (2007, p.23) memaparkan definisi kampanye yang dikemukakan oleh ilmuan atau ahli dan praktisi komunikasi diantaranya Lesile B. Snyder (2002) yang mendefinisikan A communication campaign is an organized communication activity, directed at a particular audience, for a particular periode of time to achieve a particular goal. Secara garis besar dapat diartikan sebuah kampanye komunikasi merupakan aktifitas komunikasi terorganisasi yang ditujukan kepada khalayak tertentu dalam periode yang dikhususkan untuk mencapai suatu tujuan tertentu.

Dalam Venus (2004), Charles U. Larson (1992), kampanye dapat dibagi menjadi tiga kategori yaitu: (1) Product-Oriented Campaigns: Kampanye jenis ini memiliki fokus pada bisnis, berorientasi pada produk. Tujuan dari kampanye ini adalah keuntungan finansial dengan melipat gandakan penjualan. Kampanye ini juga sering disebut commercial campaign atau corporate campaign, dan Public Relations campaign yang bertujuan menjaga image perusahaan; (2) Candidate-Oriented Campaigns: Kampanye ini berfokus kepada kekuasaaan politik dan sering disebut juga sebagai Political Campaigns. Memiliki tujuan untuk memenangkan dukungan terbanyak dari masyarakat dalam pemilihan umum demi mendapatkan jabatan-jabatan politik tertentu; (3) Ideologically or Cause Oriented Campaigns: Yaitu kampanye yang tujuan dan orientasinya besifat khusus dan dimensinya adalah perubahan sosial. Kampanye dengan jenis ini merupakan kampanye non komersil yang sering disebut sebagai Social Change Campaign. Tujuannya adalah mengubah perilaku publik sehingga masalah-masalah sosial dapat ditangani. Cakupan dari kampanye ini melingkupi kampanye yang ada dalam bidang kesehatan, kampanye lingkungan, kampanye lalu lintas, kampanye ekonomi, kampanye kemanusiaan dan juga kampanye pendidikan

Ruslan (2002), memaparkan tujuan kampanye ada dua jenis, diantaranya tujuan dalam arti sempit dan tujuan dalam arti lebih luas. Keduanya memiliki persamaan yaitu untuk menciptakan citra yang positif dimata audience. Hal ini dilakukan dengan proses komunikasi penyampaian pesan intensif dalam periode atau jangka waktu tertentu yang berkelanjutan.

Tujuan dalam arti sempit yaitu tujuan kampanye yang meningkatkan awareness, memberikan pengetahuan kepada target sasaran guna mendapatkan perhatian dan kemudian menanamkan serta menumbuhkan persepsi dan opini positif mengenai suatu kegiatan yang dilakukan oleh organisasi atau lembaga. Dalam arti yang lebih luas, kampanye memberikan penjelasan, pengertian sampai kepada memotivasi masyarakat untuk bertindak atau mengikuti program tertentu.

Proses mendesain kampanye meliputi delapan tahapannya diantaranya (Safanayong, 2006) : (1) Fakta / latar belakang / situasi yang diangkat: Latar belakang berisi fenomena yang menjadi alasan sebuah kampanye dibuat; (2) Identifikasi masalah: Masalah spesifik mengenai kasus yang diangkat dalam kampanye; (3) Analisis situasi: Analisis dari informasi relevan mengenai obyek kampanye, manfaat yang diberikan dari kampanye, dan tinjauan nilai-nilai yang diberikan dari kampanye; (4) Analisis tantangan dan peluang: Analisis meliputi faktor internal dan eksternal; (5) Strategi kampanye: Menentukan objective kampanye, target audience, dan menetapkan salah satu antara tema / keywords / positioning kampanye; (6) Komponen kampanye / media yang digunakan: Media/ komponen yang dapat digunakan yaitu poster, advertising, promosi, public relations, internet/ Interactive, direct marketing, 
selebaran / pamphlet / flyer, penjadwalan anggaran; (7) Visualisasi: Visualisasi kampanye, dari pendekatan visual diantaranya: analogi / imagery / metafor / simile / simbolis, gaya visual apa yang digunakan, pemilihan warna, dan typografi; (8) Produksi: Termasuk Pre-press dan postpress, mencakup teknik dan metode yang digunakan, material dan proses.

New media atau media online dapat diartikan sebagai produk dari komunikasi yang termediasi teknologi yang terdapat bersama dengan komputer digital (Creeber \& Martin, 2009). Media baru merupakan digitalisasi konsep pemahaman perkembangan zaman mengenai teknologi dan sains, dari semua yang bersifat manual menjadi otomatis dan dari semua yang bersifat rumit menjadi sederhana. Pentingnya Web 2.0 adalah media siar menghasilkan sebuah konteks hubungan sosial instan nasional atau internasional, ada beberapa cara di mana individu mendapatkan interaksi berharga untuk membuat koneksi global secara nyata. Faktanya bahwa pengguna sekarang dapat bekerja dengan materi media siar sebagai sebuah cara mengembangkan ide pada ruang publik (Littlejohn, 2009, p.686).

Social media adalah istilah yang mengarah kepada teknologi dan praktik online yang digunakan untuk berbagi opini dan informasi, diskusi dan membangun hubungan (Lgcommunications, 2011, p.5)

Menurut Safko dan Brake (2009, p.6), media sosial mengarah kepada aktifitas, praktik, dan perilaku didalam komunitas dimana orang-orang berkumpul secara online untuk berbagi informasi, pengetahuan, juga opini menggunakan media percakapan. Media percakapan sendiri dijelaskan sebagai aplikasi berbasis web yang memungkinan pengguna untuk membuat dan mentransmisi konten secara mudah dalam bentuk kata-kata, gambar, video, dan audio.

Media sosial memungkinkan penggunanya untuk berbagi informasi dalam percakapan online secara instan. Kebebasan informasi dan pertukarannya melalui media sosial memberikan kesempatan untuk organisasi untuk memasarkan produknya secara luas tanpa terhambat jarak dan waktu langsung kepada audiensnya. Namun disisi lain, ancaman seperti opini dan pengalaman buruk konsumen mungkin disampaikan dan tersebar di media online ini.

Karakteristik media sosial menurut Mayfield (2008) yaitu : (1) Partisipasi: Partsipasi memungkinkan pihak yang berkepentingan untuk terlibat dalam interaksi. Yaitu dengan mendorong adanya kontribusi dan feedback dari orang-orang yang tertarik, hal ini membuat media sosial mampu mengaburkan batas media dan audiencenya. Secara khusus, bentuk karakteristik ini dapat diukur. Yaitu lewat keterlibatan pengguna media sosial, frekuensi kunjungan, dan seberapa lama audience meluangkan waktunya dalam media sosial tersebut (Koh \& Kim, 2004); (2) Keterbukaan: Keterbukaan ini dapat dilihat dari bagaimana generasi muda atau pengguna internet secara umum membagikan kehidupan mereka secara online melalui situs seperti Facebook, Instagram, blog dan sebagainya. Keterbukaan yang dimaksud adalah tersedianya fasilitas untuk pengguna dapat membuat kontennya sendiri serta menyebarkan konten; (3) Percakapan: Media sosial mampu memberikan fasilitas komunikasi dua arah bukan hanya transmisi pesan satu arah yang mendistribusikan informasi kepada audience; (4) Komunitas: Media sosial dapat menghubungkan individu dan organiasasi dengan individu atau organisasi lain yang memiliki kesamaan tertentu; (5) aling Terhubung: Memungkinkan pengguna untuk berpindah ke satu titik ke titik lain dalam internet, atau 
sering disebut Link, media sosial menawarkan keterhubungan dengan penggunanya (Putri, 2018).

Webtoon berasal dari kata "web" dan "cartoon", dapat pula disebut dengan webcomic. Secara sederhana diartikan sebagai komik digital yang diterbitkan dan diakses melalui jaringan internet. Menurut McCloud (2007), dalam jaringan internet, penerbitan dan distribusi dilakukan berbarengan dan memiliki kelebihan, bisa dikatakan murah jika pembuat memiliki peralatan yang memadai. Bahkan menurutnya, jaringan internet tidak akan menjadi ujung tombak bisnis komik beberapa tahun mendatang, karena kemajuan teknologi informasi semakin berkembang. Internet harus diperhitungkan karena dapat mendapatkan pasar komik yang tidak terduga.

Dalam Oxford Dictionaries, dijelaskan kata adopsi sudah ada dari akhir abad ke-15, berasal dari bahasa Latin adoptare yang berarti to choose atau memilih. Menurut Kamus Besar Bahasa Indonesia adopsi dapat diartikan secara sederhana sebagai pemungutan. Adopsi hewan peliharaan secara umum dapat diartikan sebagai pemungutan hewan yang tidak memiliki rumah atau dari tempat tinggal sebelumnya. Hewan tersebut kemudian dirawat dan dipelihara agar mendapatkan kasih sayang lebih dan kesempatan hidup yang lebih baik.

Pengadopsian hewan dari komunitas penyelamat hewan biasanya memiliki prosedur tersendiri dan beragam sesuai dengan kebijakan masing-masing komunitas. Namun secara umum calon pengadopsi biasanya akan memilih hewan yang ingin ia adopsi atau meminta masukan dari komunitas hewan mana yang cocok untuk diadopsi, kemudian mengisi dokumen yang dibutuhkan, biasanya pengurus komunitas akan melakukan pengecekan apakah calon pengadopsi dapat memberikan pemeliharaan yang layak kepada hewan tersebut, kemudian barulah dapat mengadopsi hewan tersebut. Terkadang mengadopsi juga dikenakan biaya, bukan untuk keuntungan komunitas namun untuk biaya pengeluaran medis yang sebelumnya dijalankan oleh hewan adopsi semasa pemulihan dan tinggal di Shelter atau Foster.

Safanayong (2006) dalam bukunya yang berjudul Desain Komunikasi Visual Terpadu menjabarkan definisi desain yaitu suatu disiplin yang tidak hanya mencakup eksplorasi visual, tetapi terkait dengan aspek-aspek kultural-sosial, filosofis, teknis dan bisnis. Desain juga merupakan suatu studi yang memiliki sifat disiplin silang, dikarenakan kreatifitas dan evaluasi desain pada umumnya bersadarkan kepada model dan pelajaran disiplin lainnya.

Layout dapat didefinisikan sebagai tata letak elemen-elemen desain terhadap suatu bidang dalam media tertentu guna mendukung konsep atau pesan yang dibawanya (Rustan, 2009). Prinsip-prinsip layout menurut Rustan (2009) mencakup: (1) Sequence / Urutan: Pengaturan tata letak dari unsur-unsur desain sangatlah penting dalam layout supaya tercipta hirarki yang baik dan desain yang eratur. Juga agar audience dapat merasakan dampak yang lebih kuat setelah melihat sebuah layout; (2) Balance / Seimbang: Keseimbangan ukuran dan pengaturan setiap bagian dalam sebuah layout membuat layout lebih mudah di mengerti dan menggapai target sasarannya; (3) Rythme / Irama: Irama berupa pengulangan bentuk, unsur layout ataupun warna. Kunci utamanya adalah pengulangan secara konsisten dan bervariasi, hal ini agar sebuah layout tidak tampak membosankan; (4) Empasis / Titik Berat: Untuk menarik perhatian pembaca, pesan yang ada pada layout harus memiliki daya tarik yang 
tinggi. Pesan utamanya harus menonjol agar pembaca mengerti apa yang disampaikan; (5) Unity / Kesatuan: Agar sebuah layout memiliki visual yang enak dilihat dan tercipta keselarasan, setiap elemen dalam layout harus memiliki kesatuan.

\section{Pelaksanaan}

Menurut wawancara yang dilakukan dengan founder Let's Adopt! Indonesia didapatkan bahwa dalam kegiatan aktif volunteer, seringkali banyak persepsi yang salah yaitu apabila ada kasus kucing atau anjing sakit makan komunitas atau organisasi penyelamat akan datang tanpa pertimbangan apapun. Nyatanya komunitas-komunitas ini merupakan komunitas nonprofit, dimana tidak ada pendapatan rutin ataupun penghasilan yang masuk ke kantong pengurus, bahkan pengurus seringkali harus mengeluarkan biaya sendiri untuk melakukan kegiatan sukarela ini. Oleh karena keterbatasan biaya dan peralatan, komunitas akan mempertimbangkan beberapa faktor sebelum datang me-rescue, diantaranya jika kasus sakit, adakah klinik hewan terdekat yang buka dan setelah sembuh akan dirawat dimana, apakah ada foster yang bersedia dan adanya dana untuk makan dan merawat serta pengobatan.

Let's Adopt! Indonesia sangat mementingkan kualitas hidup setiap individu hewan yang telah di-rescue, sehingga fund raising selalu digalangkan untuk membiayai kegiatan rescue, rehabilitasi, dan adopsi. Namun adanya keterbatasan waktu dan tenaga karena pengurus komunitas sebagian besar sudah bekerja dan berkeluarga menjadi hambatan untuk selalu diadakannya event fund raising. Selain itu karena kegiatan ini berlatar belakang sosial, diharapkan pada akhirnya akan ada partisipasi dari masyarakat dalam inisiatif rescue dan adopsi.

Oleh karena itu demi mencapai tujuan utamanya menyelamatkan hewan yang membutuhkan dimanapun mereka berada, merehabilitasi, dan menemukan rumah permanen bagi hewan kucing dan anjing, diperlukan adanya kampanye untuk menyadarkan masyarakat pentingnya inisiatif dan partisipasi mengurangi populasi hewan peliharaan terlantar ini dengan rescue dan adopsi.

Media komunikasi utama yang digunakan oleh komunitas Let's Adopt! Indonesia adalah media online Facebook, Instagram, dan Twitter. Selain merupakan media komunikasi utama yang sudah memiliki audience mencapai 28.231 hingga Februari 2018, media online dipilih karena pengguna internet di Indonesia masuk ke dalam daftar terbanyak di dunia menurut data Kementrian Komunikasi dan Informatika Republik Indonesia. Media online juga telah mengalahkan berbagai media konvensional dalam durasi penggunaan setiap harinya. Media ini juga merupakan media interaktif dimana audience dapat dengan mudah melakukan aktivitas sepeti jual-beli dan transaksi lainnya. Pembaca komik di Indonesia sendiri menduduki peringkat ke dua dunia sehingga media ini dipandang efektif untuk mencapai audience yang luas.

Di era online ini, media komik yang dulunya merupakan media konvensional cetak, seperti halnya majalah, mulai mengalami krisis. Scanlator atau bisa dibilang pembajak komik sangat marak mengedarkan hasil scan komik-komik cetak ke media online yaitu website komik ilegal. Untuk memerangi kerugian yang dialami para pencipta komik, mulai bermunculan platform komik legal yang menerbitkan komik secara online baik gratis maupun berbayar. 
Line Webtoon merupakan platform online membaca komik dimana audience bisa membaca komik secara gratis serta meng-upload komik karya sendiri untuk dibaca oleh jutaan audiencenya. Line Webtoon juga merupakan platform online yang sangat digrandrungi oleh pembaca di Indonesia terbukti dari jumlah respon masyarakat terhadap aplikasi ini yang telah diunduh oleh lebih dari 10 juta kali di Indonesia sejak peluncurannya pada 2015. Platform ini juga telah tergolong sebagai media sosial karena memiliki ciri media sosial, telah memiliki komunitas yang besar mencapai jutaan akan menjadi media yang dapat mencapai audience secara luas mencakup audience usia remaja hingga dewasa.

Sarana komunikasi yang juga sangat digandrungi di era digital ini adalah Instant Messenger. Line sebagai salah satu media sosial yang paling banyak digunakan sudah menjadi bagian dari kegiatan sehari-hari masyarakat modern dalam bertukar pesan bahkan melakukan transaksi jual-beli. Fitur sticker yang dimiliki Line merupakan diferensiasi keunggulan andalan aplikasi ini. Fitur ini memberikan kemudahan pengguna untuk menunjukan ekspresi nya melalui sticker-sticker dengan gambar atau tulisan yang kreatif dan menarik. Pengguna bahkan dapat menjadi pembuat sticker sendiri dan mengunggah sticker buatannya hingga dapat dibeli oleh pengguna lainnya. Tercatat penjualan Line Sticker hingga 2014 lalu telah mencapai angka 139 miliar sehingga menjadikan Line Sticker media yang dapat menjangkau audience dan berpeluang memberikan kontribusi donasi bagi pendanaan kampanye ini.

\section{Analisis SWOT}

Strength : Let's Adopt! Indonesia memiliki tujuan yang positif bagi lingkungan masyarakat. Komunitas ini juga telah memiliki pengikut social media mencapai 28.000 dan memiliki akses kepada komunitas di empat cabang Let's Adopt di negara lainnya. Kampanye "Four Little Feet Story" ini menggunakan media webtoon atau komik digital serta publikasi online sehingga lebih mudah untuk menjangkau target audience yang berusia 16 hingga 31 tahun. Line Webtoon telah menjadi sebuah platform media sosial tersendiri yang memiliki total audience lebih dari 10 juta pembaca.

Weakness: Let's Adopt belum menjadi organisasi pencinta hewan peliharaan yang paling diingat masyarakat. Komunitas ini tidak memiliki shelter atau tempat penampungan sendiri sehingga dalam kegiatan rescue masih menitipkan hewan di klinik atau foster. Let's Adopt belum pernah melakukan kampanye yang spesifik selain kampanye event steril bersubsidi.

Opportunity: Berdasarkan hasil kuisioner yang disebarkan kepada pembaca webtoon atau komik online, $89,2 \%$ orang menyukai anjing atau kucing, $75,7 \%$ menyatakan merasa kasihan terhadap anjing atau kucing liar, dan 70,3\% menyatakan tertarik untuk memelihara anjing atau kucing. Sehingga pembaca webtoon merupakan audience yang tepat untuk kampanye ini. Media yang digunakan dalam kampanye ini memiliki fitur berbagi atau share sehingga memudahkan penyebarluasan kampanye ini.

Threat: Persepsi bahwa anjing dan kucing yang hidup di jalan atau terlantar dianggap sudah biasa berkeliaran di jalanan, dan dibiarkan mencari makan di tempat-tempat sampah.

Kampanye Rescue and Adopt "Four Little Feet" bertujuan untuk memberikan kesadaran kepada target audience bahwa setiap individu hewan memiliki hak hidup yang sama dan penting adanya inisiatif dan partisipasi masyarakat dalam kegiatan rescue dan adopsi yang bermanfaat menanggulangi populasi hewan peliharaan terlantar di Indonesia. 
Penyampaiannya dilakukan dengan memanfaatkan media online Line Webtoon. Selain itu akan dimanfaatkan pula pembuatan Line Sticker serta publikasi melalui media sosial Facebook, Instagram dan Twitter untuk meningkatkan view serta memberikan informasi yang lebih lengkap mengenai kampanye sosial ini.

Tema yang diangkat sesuai dengan obyektif komunitas untuk menyelamatkan hewan yang membutuhkan dimanapun mereka berada, dan sesuai untuk memberikan solusi kepada tantangan utama yang dihadapi komunitas ini yaitu masih kurangnya inisiatif dan partisipasi masyarakat dalam kegiatan rescue dan adopsi.

Kampanye ini memanfaatkan media utama cerita dan visual komik online platform Line Webtoon. Formatnya adalah komik scroll mengikuti format yang dianggap paling sesuai untuk display atau dibaca menggunakan smartphone dan personal computer. Genre komik ini adalah drama dan slice of life, terinspirasi dari kisah nyata untuk lebih mendekatkan pembaca kepada nilai emosional yang disampaikan. Strategi yang digunakan yaitu dengan mengangkat kisah yang terinspirasi dari kisah nyata, dengan tokoh utama bagian masyarakat biasa sehingga masyarakat yang membaca sendiri dapat merasakan ada relasi dengan tokoh dalam komik.

Sudut pandang yang digunakan yaitu sudut pandang orang pertama yaitu tokoh utama kucing dan anjing. Tokoh utamanya diantaranya Meong sang kucing rumah kosong, Kakek yang baik hati, Rocky anjing berbulu hitam yang dilempari batu, dan anjing serta kucing yang diselamatkan oleh komunitas Let's Adopt.

Kisah webtoon ini berawal dari petualangan hidup seekor kucing kecil yang tinggal di halaman sebuah rumah kosong. Tepat disamping rumah kosong tersebut tinggal seorang kakek yang juga sebatang kara yang memanggilnya Meong. Kucing rumah kosong digambarkan sebagai hewan peliharaan yang terlantar dan hidup dijalanan, beruntungnya ada kakek yang penuh belas kasih yang dengan setia menyisihkan makanannya untuk kucing kecil serta menyapu halaman rumah kosong tempat kucing kecil tidur. Kucing kecil seringkali menghampiri kakek dan berjalan mengikuti kakek, dengan penuh kasih sayang sang kakek juga tidak jijik mengelus kepala Meong yang seringkali terpaksa berkeliaran dijalan dan mencari sisa makanan di tempat sampah. Sayangnya seiring berjalannya waktu, kakek sudah semakin tua hingga suatu hari Meong harus menerima kenyataan kakek yang ia sayangi tidak kembali setelah mobil ambulance membawanya pergi. Kucing kecil harus kembali mengais-ngais makanan di tempat sampah, tempat tidurnya pun kotor karena tidak dibersihkan. Sampai ia akhirnya menderita kelaparan karena sulitnya mencari makanan di tempat sampah. Kemudian cerita beralih sementara ke tokoh utama lainnya seekor anjing hitam, yang menceritakan kenyamanan hidupnya dengan dirumah dan betapa ia menyayanyi pemiliknya. Ternyata anjing ini adalah anjing yang diadopsi dan diberi nama Rocky .

Cerita berlanjut dengan alur mundur, mengisahkan Rocky yang juga merupakan hewan peliharaan yang lahir dan hidup di jalanan, walau begitu karena belas kasih beberapa warga sekitar, si anjing dapat bertahan hidup. Sayangnya ada kalanya ia bertemu dengan orang yang kurang bertanggung jawab dan mendapat perlakuan tidak baik, ia dilempari batu sampai mengenai kepalanya. Anjing hitam kecil tersebutpun tidak sadarkan diri, beruntungnya ditolong oleh warga sekitar yang kemudian dibantu oleh komunitas penyayang binatang dan 
dibawa ke klinik. Setelah pulih Rocky hidup dengan foster parent menunggu untuk diadopsi bersama dengan anjing dan kucing lain. la menceritakan bahwa kehidupan di foster telah jauh lebih baik dibanding di jalanan, namun ia masih merasa ada yang kurang, secara insting Rocky masih menantikan sebuah rumah yang hangat dan pemilik yang dapat ia cintai sepenuh hati. Beruntungnya Rocky bertemu dengan adopternya sekarang, ia sudah menemukan hal yang paling ia idamkan, rumah yang penuh kasih sayang yang manusia untuk ia cintai. Rocky kemudian berharap semua teman anjiing dan kucingnya yang masih hidup di jalan beserta seekor kucing kecil yang baru saja dirawat bersamanya di foster home mendapatkan kasih sayang yang sama dan rumah mereka sendiri. Kucing kecil tersebut adalah kucing rumah kosong yang telah sendirian tanpa kakek, yang hampir mati kelaparan namun ditolong oleh warga.

Cerita kemudian berakhir dengan ilustrasi kebersamaan Rocky dan pemiliknya. Serta kenangan kucing kecil dengan kakek, lalu pesan bahwa banyak kucing dan anjing seperti Meong sekarang menunggu adopter yang siap untuk menerimanya apa adanya, dan ia siap untuk menyayangi mereka sepenuh hati. Di sediakan juga informasi kontak komunitas Let's Adopt! Indonesia, untuk dapat mengadopsi atau berpartisipasi dalam kegiatan rescue.

Materi e-poster akan publish sehari sebelum webtoon publish dan pada hari publish. Materinya berisi perkenalan akan tokoh-tokoh dalam webtoon "Four Little Feet Story", untuk memperkenalkan webtoon yang akan publish. Setiap minggunya juga pada media sosial Instagram, Facebook dan Twitter Let's Adopt akan di post reminder untuk para pembaca, pada hari publikasi webtoon juga akan dipost cover webtoon episode minggu tersebut, dengan caption pertanyaan untuk melihat respon dari pembaca. Pertanyaan kira-kira bagaimana pendapat pembaca mengenai tokoh Meong yang diceritakan, lalu pertanyaan apakah di sekitar rumah pembaca ada kucing terlantar seperti tokoh Meong. Untuk membuat audience tertarik untuk memberi feedback, setiap minggu akan dipilih komentar terbaik yang inspiratif untuk mendapatkan Line Sticker kampanye "Four Little Feet" secara gratis dan diumumkan di posting minggu berikutnya.

Sticker Line akan mengikuti konsep webtoon pada ilustrasinya, namun berfokus kepada emosi-emosi yang sering digunakan pada platform Social Messenger misalnya Good Night, Lunch Time, dan Thank you. Ilustrasinya menggunakan tokoh-tokoh yang muncul dalam webtoon. Sehingga tujuannya untuk mengingatkan, dan juga dapat menjadi media berdonasi bagi pembaca.

Konten yang akan disampaikan dalam bahasa Indonesia karena terbit di Line Webtoon Indonesia dan ditujukan bagi pembaca di Indonesia, pada e-poster dan Line Sticker akan menggunakan bahasa Indonesia dan bahasa Inggris, audience media social Let's Adopt sendiri secara general menggunakan bahasa Inggris dalam setiap postingnya namun untuk informasi lebih detail akan dijelaskan dengan bahasa Indonesia sehingga lebih mudah dimengerti.

Selain konten reminder untuk membaca webtoon, juga akan disampaikan informasi mengenai kegiatan rescue dan adopt diantaranya tata cara sederhana untuk melakukan kegiatan rescue untuk hewan yang sakit, dan proses untuk dapat mengadopsi melalui komunitas Let's Adopt! Indonesia. 


\section{Analisis Target}

Demografis target adalah sebagai berikut. Berusia, 16-31 tahun, jenis kelamin Pria dan Wanita dengan pendidikan SMA, D3, dan S1. Pekerjaan sebagai mahasiswa, karyawan, atau wiraswasta dengan kelas sosial B dan A. Secara geografis berdomisili di Jakarta. Psikografis Interest Menyukai kucing dan anjing, behaviour mempunyai gaya hidup dan cara berkomunikasi yang modern dan dinamis, merupakan pengguna internet aktif, bertukar informasi melalui internet dan social media. Attitude mempunyai rasa simpatik, suka bersosialisasi, peduli akan lingkungan sekitar, rasa tanggung jawab yang tinggi. Opinion belum mengetahui pentingnya inisiatif dan partisipasi masyarakat dalam upaya mengurangi populasi hewan peliharaan terlantar di Indonesia yang bermanfaat bagi lingkungan.

Alasan pemilihan khalayak sasaran kampanye ini seperti dipaparkan diatas adalah pertimbangan target audience komunitas Let's Adopt yang sebenarnya sangat luas, dari anakanak sampai dewasa, namun akhirnya dikerucutkan agar teknik penyampaian pesan bisa efektif dan terfokus. Rentang usia yang dipilih adalah 16 hingga 31 tahun, yaitu remaja dan dewasa muda yang aktif menggunakan media online yang juga merupakan rentang usia pembaca Line Webtoon (Putri, 2018). Selain itu Let's Adopt sendiri fokus kepada komunikasi melalui media digital, dimana media komunikasi utamanya adalah Facebook, Instagram dan Twitter. Media sosial dan Social Messenger sebagai media tambahan dalam kampanye ini juga merupakan media yang penggunanya merupakan remaja dan dewasa muda.

Usia remaja dipilih agar kampanye ini dapat menanamkan pengertian sejak dini, juga dipertimbangkan bahwa pada usia remaja mulai 16 tahun mulai dituntut memiliki rasa tanggung jawab yang lebih dibandingkan sebelumnya karena umumnya pada usia ini remaja sudah harus menentukan rencana masa depan seperti pengambilan jurusan dan perguruan tinggi yang dipilih atau kantor tempat magang untuk pelajar sekolah penjurusan. Diharapkan mulai usia ini juga remaja bisa mulai mengerti mengenai manfaat sosial kampanye ini. Usia mencapai 31 tahun juga dipilih sebagai rentang usia dewasa muda yang sudah mulai mapan dan memiliki penghasilan sehingga dapat berkontribusi untuk kepentingan lingkungan. Domisili di Jakarta karena penggunaan media online yang mencakup perkotaan dan kota terbesar sehingga Jakarta dapat dijadikan model untuk kampanye meningkatkan awareness yang berdurasi 3 bulan ini.

\section{Positioning}

Positioning yang akan ditanamkan ke benak target audience adalah setiap individu kucing dan anjing memiliki hak hidup yang sama dan pada dasarnya kucing dan anjing merupakan hewan domestik sehingga kesempatan hidup terbaik mereka adalah hidup bersama manusia sebagai hewan peliharaan. Oleh karena itu inisiatif masyarakat dalam kegiatan rescue dan adopsi merupakan solusi yang baik untuk meningkatkan kesejahteraan hewan peliharaan, serta berdampak baik bagi lingkungan dan kesehatan masyarakat.

Kampanye ini diharapkan memberikan pengertian kepada target audience tanpa kesan menggurui namun tetap sesuai dengan prinsip Let's Adopt yaitu kualitas hidup setiap individu hewan sangatlah penting. Pesan kampanye disampaikan melalui cerita potongan kehidupan hewan-hewan peliharaan yang terlantar, sakit dan tersiksa. Dalam cerita ini akan ditanamkan pesan bahwa setiap orang dalam masyarakat dapat berinisiatif untuk melakukan kegiatan 
rescue dan adopsi. Serta betapa besar peran masyarakat dalam memperjuangkan kesejahteraan hewan-hewan tersebut akan berdampak bagi diri sendiri dan lingkungan.

Kampanye sosial ini kan dilaksanakan selama 3 bulan pada tahun 2018, dari tanggal 19 Juli hingga 4 Oktober bertepatan dengan Hari Hewan Sedunia. Konten Line Webtoon akan di upload setiap kamis per episodenya, dan konten e-poster akan dipublish setiap Rabu untuk mengingatkan audience bahwa sehari setelahnya webtoon akan publish, dan Kamis setelah di upload untuk mengontrol reaksi dari pembaca dengan melempar pertanyaan memancing reaksi dari audience yang akan penting untuk evaluasi kampanye.

Media yang akan dibuat dalam perancangan kampanye ini adalah media online. Berdasarkan hasil kuisioner didapat bahwa dari keseluruhan responden pembaca webtoon 97,3\% menggunakan internet setiap hari selama lebih dari 3 jam sehingga media online dapat mencapai audience secara efektif. Media-media online berikut juga merupakan media online yang paling banyak diakses oleh target audience, diantaranya:

\section{Webtoon atau komik digital}

Webtoon adalah inovasi dari buku komik tradisional, webtoon diterbitkan secara digital melalui website atau aplikasi tertentu dan berbasis internet. Media ini menyediakan sarana hiburan melalui cerita dalam bentuk visual, sehingga dianggap menarik sebagai bentuk kampanye inovatif dan lebih efektif dalam menyampaikan pesan yang menyentuh emosional audience. Hal ini dikarenakan sebagian besar pembaca webtoon membaca pada saat waktu santai, sehingga penyampaian pesan akan lebih mudah ditangkap audience.

Gaya penulisan naskah webtoon menggunakan pendekatan emosional, dengan menonjolkan interaksi emosional diantara hewan dan manusia. Serta personifikasi dimana sudut pandang yang dipakai adalah sudut pandang orang pertama yaitu sudut pandang kucing dan anjing yang merupakan tokoh utama cerita.

Webtoon akan dipublikasikan di Line webtoon sebagai platform webtoon terpopular di Indonesia, juga diposting di media sosial Let's Adopt (Facebook, Twitter, dan Instagram). Fitur Share dan Comment, juga memberikan kemudahan bagi tersebarnya informasi dan komunikasi dalam kampanye ini.

\section{E-Poster (Media Sosial)}

Target audience pengakses internet menyatakan bahwa platform pertama yang diakses adalah media sosial, dari hasil kuisioner didapat $94,6 \%$ responden menggunakan internet untuk mengakses platform ini. Sebanyak 40,5\% responden juga berpendapat bahwa kampanye dengan media poster menarik perhatian merek.

E-Poster akan didesain untuk mempublikasikan Webtoon yang telah dibuat dengan menggunakan illustrasi karakter yang muncul pada webtoon. Poster akan diposting secara digital bekerja sama dengan website, blog, dan media sosial pencinta binatang serta dokter hewan terkemuka (seperti dr. Magda, dr. Cucu, Pejaten Shelter, JAAN, binatang.net, pecintahewan.com, dan okdogi.com), dan media sosial Let's Adopt (Facebook, Twitter, dan Instagram). 
Media sosial akan berfungsi sebagai publikasi serta penyedia informasi lebih lanjut mengenai kampanye ini. Dengan melakukan iklan, melalui Instagram Ads dan Facebook Ads, kampanye ini akan dapat menjangkau audience yang lebih luas.

\section{Sticker Line}

Sticker Line adalah item bergambar setara dengan emoticon yang dapat digunakan untuk menunjukkan emosi dalam pembicaraan virtual melalui aplikasi online chat LINE. Budaya komunikasi melalui Instant Messenger sendiri sudah menjadi keseharian bagi para pengguna internet aktif, dikarenakan ekonomis, cepat, akurat serta memiliki fitur yang menarik. Bagi pengguna Line Messenger, Sticker sudah menjadi fitur yang wajib digunakan untuk berekspresi dalam penyampaian pesan, dapat dilihat dari minat beli masyarakat terhadap Sticker Line yang mencapai milyaran.

Sticker yang akan dibuat sesuai dengan karakter yang muncul dalam webtoon, dengan desain anjing dan kucing lucu. Pemilihan media ini dikarenakan Sticker Line dapat di beli melalui Line Store oleh siapapun pengguna aplikasi line, selain itu hasil pembelian sticker Line ini akan digunakan untuk biaya kampanye dan penyelamatan hewan-hewan terlantar (operasi rescue).

\section{Visualisasi}

Proses pembuatan webtoon dan materi promosi dimulai dengan sketching. Proses sketching pertama-tama untuk merancang master design, sehingga mempermudah perancang dalam membuat desain dengan software komputer dalam bentuk digital.

Gambar 5. Sketsa diambil dari Rancangan Desain Pembuat Karya, 2018

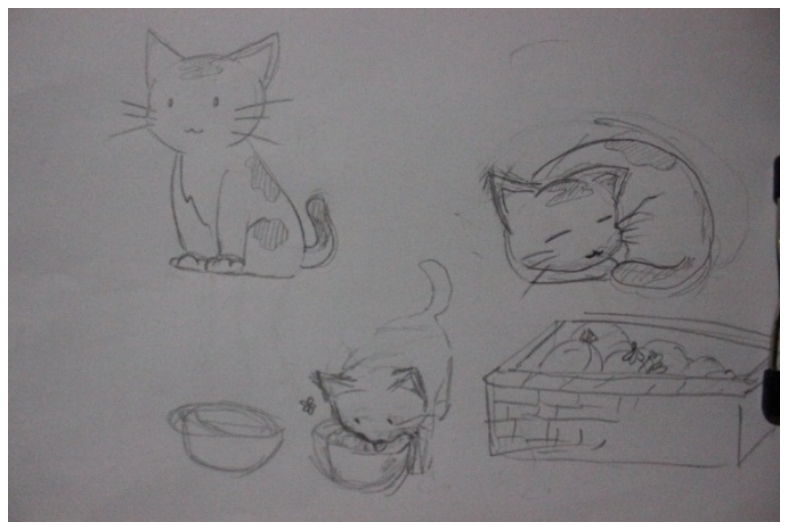

Gambar 6. Sketsa diambil dari Rancangan Desain Pembuat Karya, 2018
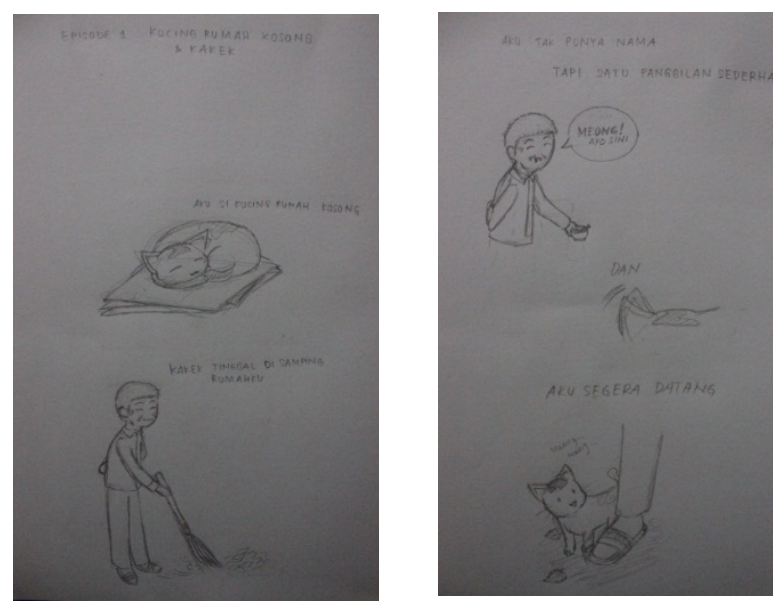
Gambar 7. Logo Webtoon, dari hasil karya penulis 2018

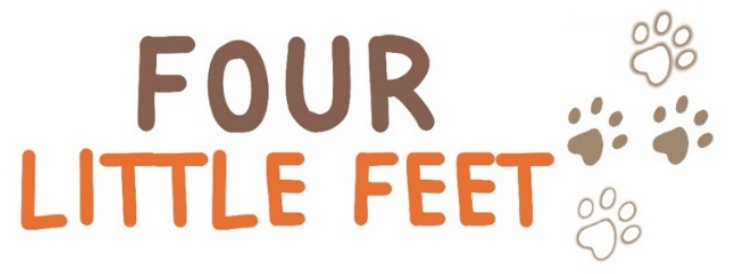

Gambar 8. posting social media, dari hasil karya penulis 2018
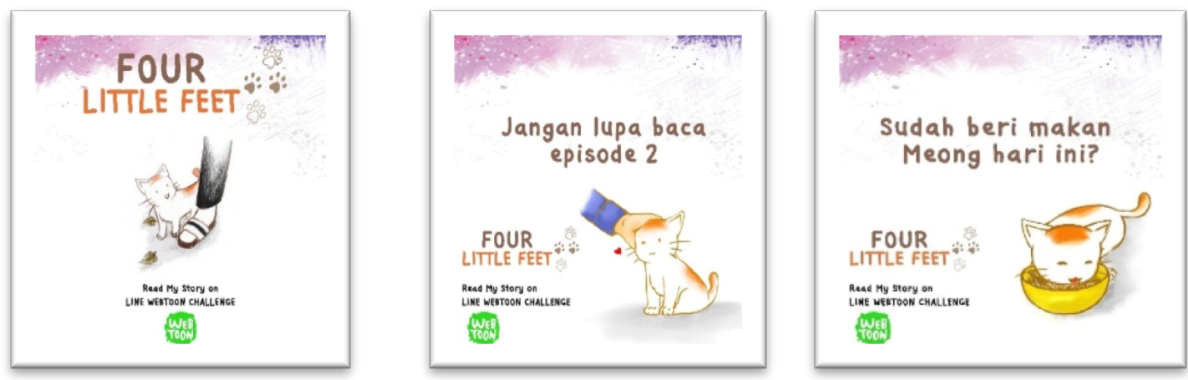

Gambar 9.Webtoon, dari hasil karya penulis 2018

AKU TAK PUNYA NAMA

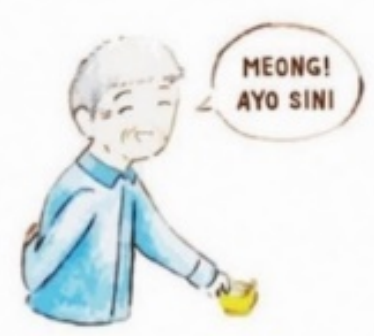

TAPI SATU PANGGILAN SEDERHANA

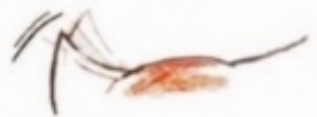

EPISODE 1

"KUCING RUMAH KOSONG DAN KaKEK"

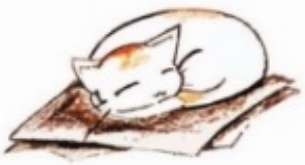

AKU SI KUCING RUMAH KOSONG

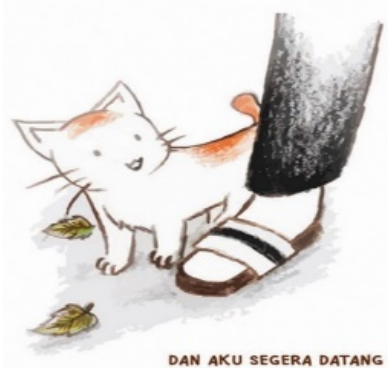

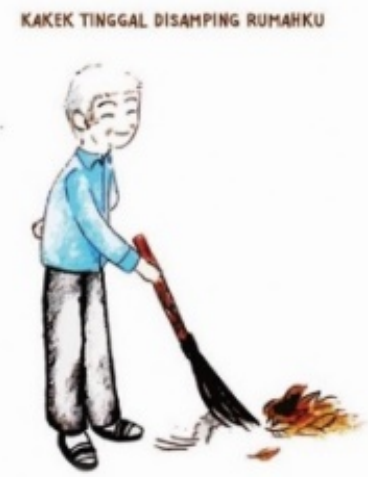


Gambar 10. Webtoon dari hasil karya penulis 2018

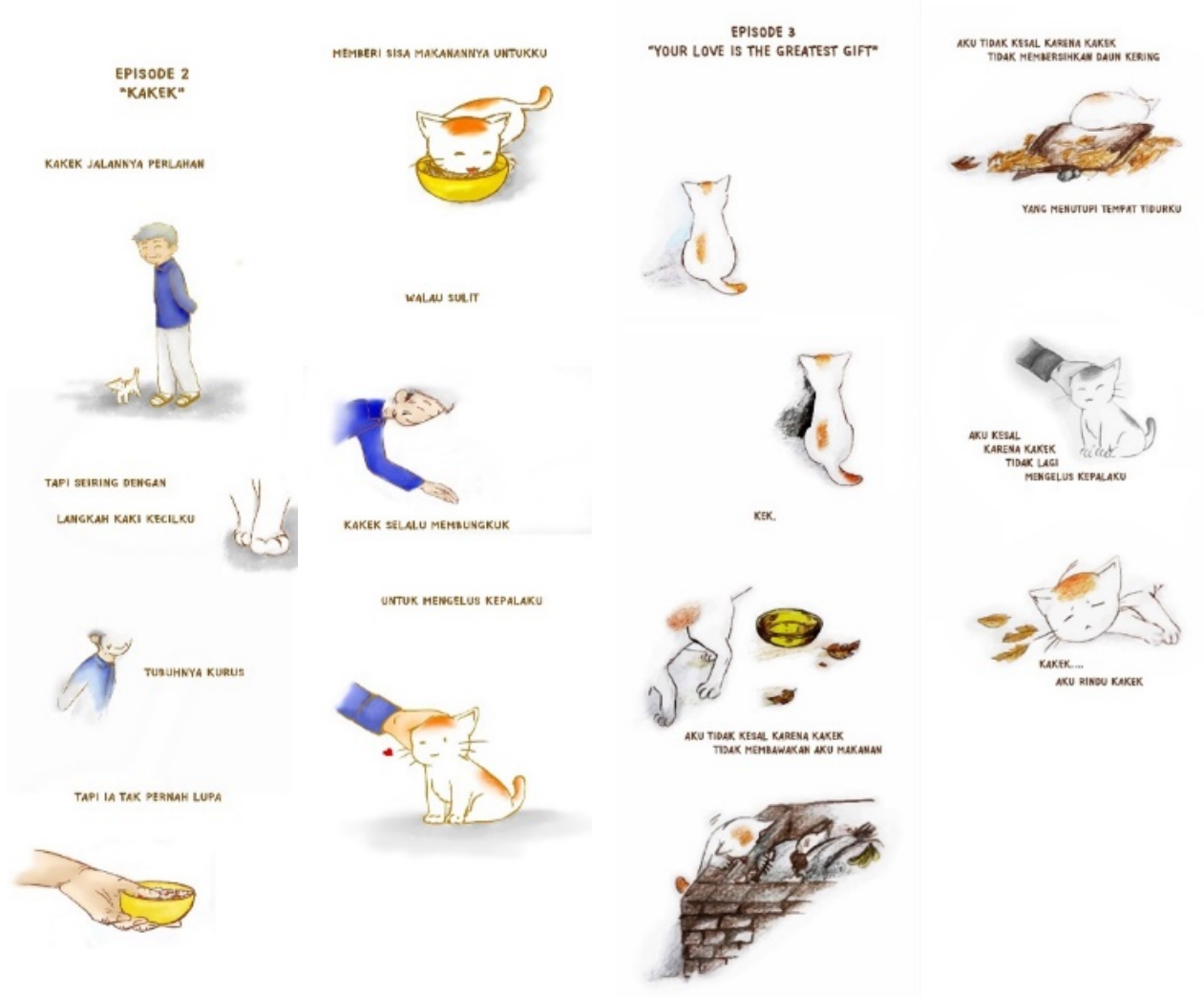

\section{Konsep Visual}

Sesuai dengan hasil analisis kuisioner bahwa sebagian besar target audience merasa kasihan jika melihat anjing atau kucing terlantar, maka perancang akan menggunakan cerita dengan tema drama dan potongan kehidupan (slice of life) yang terinspirasi dari kisah nyata. Sebanyak $51,4 \%$

responden juga menyatakan genre drama sebagai salah satu genre webtoon favorit mereka. Sudut pandang cerita diambil dari sudut pandang anjing dan kucing terlantar yang ingin diadopsi atau sudah diadopsi, konsep webtoon tidak menampilkan banyak tulisan namun lebih menekankan ilustrasi yang sederhana dan menyentuh. Dengan cerita yang bertemakan drama ini diharapkan dapat membangkitkan rasa empati audience. Format komik Line Webtoon berbasis online dengan cover maksimum 161 x 151 pixel dan maksimal $500 \mathrm{~kb}$, dan ukuran komik maksimum 800 x 1280 pixel, maksimum ukuran per episode 20 mb.

\section{Produksi}

Berikut adalah biaya produksi dan media yang diperlukan dengan jangka waktu kampanye 3 bulan. Tabel dalam hitungan rupiah.

Tabel 1. Tabel biaya perancangan dan produksi kampanye

\begin{tabular}{|l|l|}
\hline & Biaya \\
\hline Konsep perancangan kampanye & 3.000 .000 \\
\hline Penulisan cerita webtoon & 1.000 .000 \\
\hline Ilustrasi webtoon & 3.500 .000 \\
\hline
\end{tabular}




\begin{tabular}{|l|l|}
\hline Ilustrasi sticker Line & 1.000 .000 \\
\hline Facebook dan Instagram Ads & 600.000 \\
\hline TOTAL & $\mathbf{9 . 1 0 0 . 0 0 0}$ \\
\hline
\end{tabular}

Olahan Pembuat Karya 2018

\section{Evaluasi}

Metode yang digunakan untuk evaluasi kampanye ini adalah metode survey kepada pembaca Webtoon dan pengikut media sosial Let's Adopt. Evaluasi dilakukan dengan mengajak lewat media sosial Let's Adobe dan pada kolom komentar di platform Line Woobton agar followers mengiri formulir Survey secara online, dengan menyertakan akun Instagram mereka sehingga 5 orang beruntung bisa mendapatkan ilustrasi gambar mereka dengan hewan peliharaan kesayangan mereka. Survey akan dilakukan satu minggu setelah kampanye ini selesai yaitu tanggal 11 okober 2018 dan periode 2 minggu

\section{SIMPULAN}

Telah dibuat dummy Webtoon yang diterbitkan di platform Webtoon Challenge, dan dapat dilihat respon pembaca. Webtoon sebanyak dua episode sudah diupload dan dibaca sebanyak 11.005 kali sejak terbit pada Desember 2017. Jumlah Like nya adalah 749 dan ratingnya 9,78 dari nilai sempurna 10. Secara general dapat disimpulkan bahwa respon pembaca cukup baik dengan total komentar 89 kebanyakan membahas mengenai hewan peliharaan pembaca, maupun kesukaan pembaca terhadap hewat.

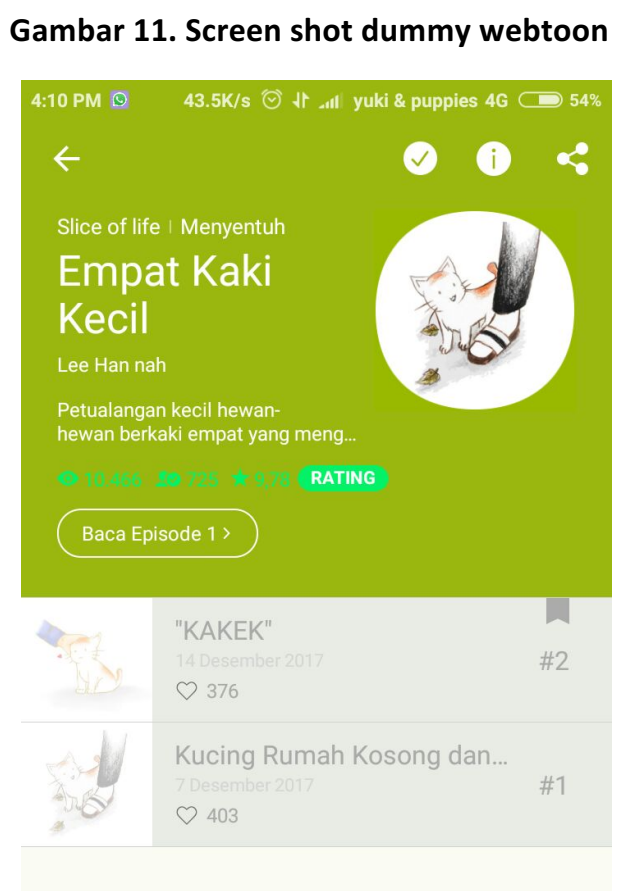

Sumber: Data Olahan Peneliti, 2018 
Gambar 12. Screen shot komentar dummy webtoon

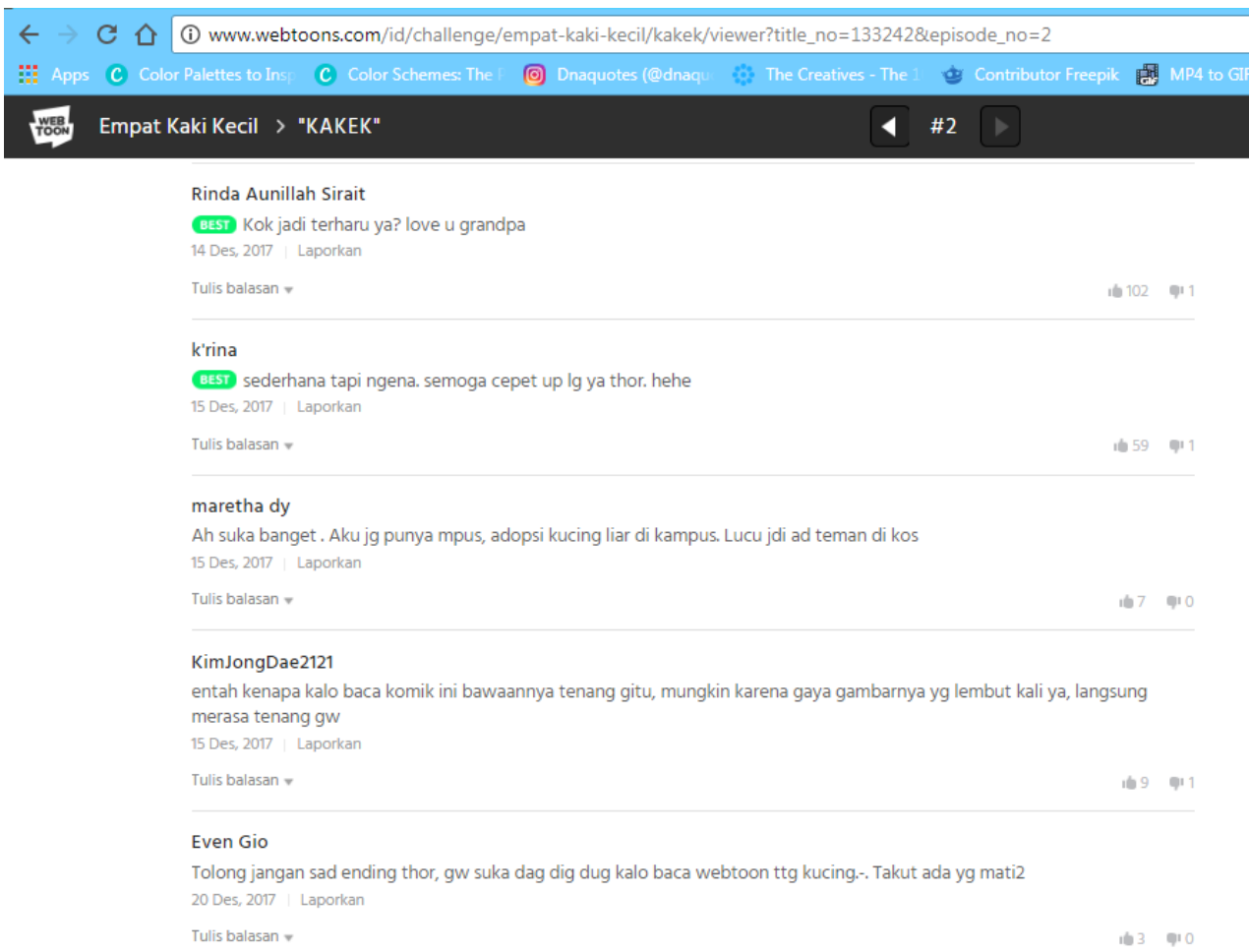

Sumber: Data Peneliti, 2018 


\section{DAFTAR PUSTAKA}

74 kasus Rabies di Bali . (2010, Agustus 2). Diperoleh pada Maret 10, 2017, dari bbc.com: http://www.bbc.com/indonesia/berita_indonesia/2010/08/100802_balir

abies.shtml?print $=1$

Alexander, H. B. (2016, Februari 4). Kelas Menengah, Penggerak Utama Pasar Properti Indonesia. Diperoleh dari website Kompas.com:

http://properti.kompas.com/read/2016/02/04/121204221/Kelas.Menen gah.Penggerak.Utama.Pasar.Properti.Indonesia?page=all

Brake, L. S. (2009 ). The Social Media Bible: Tactics, Tools, and Strategies for Business Success. Ney Jersey : John Wiley \& Sons, Inc.

Buckey, C. (2013, Juli 8 ). Pet Adoption Poster Series. Diambil kembali dari behance.net: https://www.behance.net/gallery/9700799/Pet-Adoption-Poster-Series

Creeber G. dan Martin R. (2009). Digital Cultures. New York: Open University. Press.

Companian Animal Overpopulation. (n.d.). Diperoleh pada Maret 15, 2017, dari peta.org: http://www.peta.org/issues/companion-animal-issues/overpopulation/

Dari Hobi Jadi Hoki : Menangkar Kucing \& Anjing (2). (2009, Januari 5). Diperoleh pada Maret 10, 2017, dari Kompas.com:

http://nasional.kompas.com/read/2009/01/05/15372565/dari.hobi.jadi.h oki..menangkar.kucing..anjing.2

Hidayat, Rahmat. (2010). Cara Praktis Membangun Website Gratis :Pengertian Website. Jakarta : PT Elex Media Komputindo Kompas,Gramedia

Kresna. (2014, Maret 5). Danang si penembak kucing dilaporkan ke Polres Sleman. Diambil kembali dari merdeka.com: https://www.merdeka.com/peristiwa/danangsi-penembak-kucing-dilaporkan-ke-polres-sleman.html

Ha Sun Jin, L. S. (2012, April 9). Webtoon, Why So Popular? Retrieved from The Dongguk Post: https://www.dgupost.com/news/articleView.html?idxno=1247

Isparmo. (2016, November 21). Data Statistik Pengguna Internet Indonesia Tahun 2016. Diambil kembali dari isparmo.web.id: http://isparmo.web.id/2016/11/21/datastatistik-pengguna-internet-indonesia-2016/

Kresna. (2014, Maret 5). Danang, si penembak kucing dilaporkan ke Polres Sleman. Diperoleh dari website merdeka.com: http://www.merdeka.com/peristiwa/danangsi-penembak-kucing-dilaporkan-ke-polres-sleman.html. 
Lefebvre, R. C., (2011). An Integrative Model for Social Marketing. Journal of Social Marketing 1. pp.54-72, doi: 10.1108/20426761111104437

Lister, M., Dovey, J., Giddings, S., Grant, I., \& Kelly, K. (2009). New Media, A Critical Introduction (2nd Edition ed.). Routledge.

Littlejohn, Stephen W., dan Karen A. Foss. 2009. Teori Komunikasi: Theories of. Human Communication, Edisi 9. Jakarta: Salemba Humanika.

Kay, L. (n.d.). Dog Rescue Stories: Patrick the Survivor was Hacked With a Cleaver and Left for Dead by an Angry Mob. Diperoleh pada Maret 16, 2017, dari positivelywoof.com: http://positivelywoof.com/dog-rescue-stories-patrick-the-survivor-was-hacked-witha-cleaver-by-an-angry-mob-and-left-for-dead/

Kemp, S. (2016). Special Reports: Digital in 2016. Diperoleh pada Januari 112017 dari http://wearesocial.com/uk/special-reports/digital-in-2016

LGcommunications. (2011). Guide to Social Media. London: LGcommunications.

Julianto, P. A. (2016, April 10). Komunitas Pecinta Hewan Meningkat,Indonesia Pet Expo 2016 Targetkan 25 Ribu Pengunjung. Diperoleh dari Kompas.com: http://bisniskeuangan.kompas.com/read/2016/04/10/203208426/Komunitas.Pecinta. Hewan.Meningkat.Indonesia.Pet.Expo.2016.Targetkan.25.Ribu.Pengunjung

Kotler, P. (2002). Social Marketing: Improving the Quality of Life. California: Sage Publication.

Kotler, P., \& Lee, N. R. (2009). Up and Out of Poverty (The Social Marketing Solution. New Jersey: Pearson Education, Inc.

Moriarty, S., Mitchell, N., \& Wells, W (2011). Advertising Edisi Kedelapan. Jakarta: Prenada Media Group.

Pengguna Internet Indonesia Nomor Enam Dunia. (2014, 11 24). Diperoleh pada Februari 20, 2017, dari website Kominfo:

https://kominfo.go.id/content/detail/4286/pengguna-internet-indonesia-nomorenam-dunia/0/sorotan media

Putri, D. M. (2018). Pengaruh Media Line Webtoon Terhadap Minat Membaca Komik pada Mahasiswa Riau. JOM FISIP, 1.

Rio. (2013, Mei 13). 325 Anjing dan Kucing Divaksin Antirabies. Diperoleh dari website Pemerintah Kota Jakarta: http://www.jakarta.go.id/v2/news/2013/05/325-anjingdan-kucing-divaksin-antirabies\#.VjiMtyvQMg4

Risma. (2016, April 10). Akhir September, Indonesia Pet Expo 2016 Digelar. Diperoleh dari Jakartakita.com:http://jakartakita.com/2016/04/10/akhir-september-indonesia-petexpo-2016-digelar/

Ruslan, Rosady. 2007. Manajemen Public Relations \& Media komunikasi. Jakarta: PT Raja Grafindo Persada. 
Ryan, D., \& Jones, C. (2009). Understanding Digital Marketing : Marketing Strategies for Engaging Digital Generation. Great Britain and the United States : Kogan Page Limited.

Setiawan, R. (2014, Juli 24 ). Video Suntik Mati Anjing di Bali Jadi Sorotan Media Asing. Diambil dari suara.com : http://www.suara.com/news/2014/07/24/171128/videosuntik-mati-anjing-di-bali-jadi-sorotan-media-asing

Smiciklas, M. (2012). The Power of Infographics: Using Pictures to Communicate and Connect With your audiences. USA: Pearson Education, Inc.

Utomo, Y. W. (2012 , April 15 ). Utamakan Adopsi Anjing. Diambil dari kompas.com: http://tekno.kompas.com/read/2012/04/15/19242653/ Sains Umum Yuliarti, Nurhaeti. (2007). Hidup Sehat Bersama Hewan Peliharaan.Yogyakarta: Andi Offset 